\title{
Comparison of generalist predators in winter- flooded and conventionally managed rice paddies and identification of their limiting factors
}

\author{
Mayura B Takada ${ }^{*}$, Shun Takagi ${ }^{2}$, Shigeki Iwabuchi ${ }^{3}$, Takuya Mineta ${ }^{4}$ and Izumi Washitani ${ }^{5}$
}

\begin{abstract}
Winter-flooding of rice paddies without the application of agricultural chemicals is attracting attention as a new agricultural method for enhancing the habitat conditions of wintering waterfowl in rice paddy ecosystems throughout Japan and east Asia. Conditions in these paddies are expected to result in restoration of not only the winter habitats of waterfowl but also those of other taxonomic groups during the rice growing season. In this study, we tested whether the diversity of summer spiders--ubiquitous predators in rice paddies--was higher in the winter-flooded paddies than in the conventional ones by conducting field measurements in 31 winter-flooded and 7 conventional paddies. Limiting factors of spiders in the winter-flooded paddies were then examined. Results revealed that both the density and species richness of spiders were significantly higher in the winter-flooded paddies than in the conventional ones both before and after the insecticide application against pecky rice bug Stenotus rubrovittatus (Matsumura)(Hemiptera: Miridae) to conventional paddies. In addition, spider density and species richness in the winter-flooded paddies correlated with the availability of two prey groups--chironomids and other nematocera. These findings suggest that in the winter-flooded paddies the diversity of generalist predators is higher than in the conventional ones during the rice-growing season and that the combination of management at both the landscape and field level is likely more effective for increasing spider abundance in winter-flooded paddies.
\end{abstract}

Keywords: Biodiversity-friendly farming; Natural enemy; Restoration; Spiders; Waterfowl; Wetland

\section{Introduction}

Biological communities in agricultural crop fields that have received low or no chemical application are more diverse than those of conventionally farmed fields (e.g. Bengtsson et al. 2005). In particular, rice paddies maintained by biodiversity-friendly farming techniques are expected to function as important substitute habitats for organisms in natural wetlands, which have declined due to the development of urban and agricultural fields (Fasola and Ruiz 1997; Washitani 2007).

The farming practices of biodiversity-friendly paddy fields include the winter flooding of paddies to enhance the habitat conditions for wintering waterfowl (Elphic and Oring 1998; Tourenq et al. 2003; Kurechi 2007). In the paddies at the Ramsar wetland site that surrounds

\footnotetext{
* Correspondence: mayura@isas.a.u-tokyo.ac.jp

${ }^{1}$ Institute for Sustainable Agro-ecosystem Services, University of Tokyo,

Midori-cho, Nishi-Tokyo, Tokyo 188-0002, Japan

Full list of author information is available at the end of the article
}

the natural Kabukuri-numa Wetlands, which is one of the most important wintering sites for geese in Japan, the winter-flooding regime combined with no agricultural chemical applications has become a growing trend. This farming method is attracting attention as a new biodiversity-friendly approach throughout Japan and East Asia (Kurechi 2007; Washitani 2007). In fact, to restore paddy biodiversity including wintering waterfowl, no agricultural chemicals have been applied to the winterflooded (WF) paddies in this region since around 1998. Moreover, WF paddies are also expected to enhance ecosystem services for rice production, including the biological control of insect pests by generalist predators.

In this study, the diversity of spiders--ubiquitous predators in rice paddies--was compared between WF and conventional paddies through field measurements conducted in $31 \mathrm{WF}$ paddies and 7 conventional ones. In addition, factors limiting the abundance of spider populations in WF paddies were also examined. Crop 
yield in biodiversity-friendly fields can be low compared with that in paddies that receive conventional chemical applications (de Ponti et al. 2012). Thus, effective pest management techniques other than the use of insecticides are needed to sustain growth in biodiversity-friendly farming (Zehnder et al. 2007). Identifying the limiting factors of generalist predators in the WF paddies can help with the construction of effective management plans for insect pest control, because our previous studies showed that the spiders predate insect pests (Kobayashi et al. 2011; Takada et al. 2013), and suppress the density and the consequent damage in organic paddy fields (Takada et al. 2012). Spider population growth is known to be constrained by habitat complexity (Langellotto and Denno 2004; Takada and Miyashita 2004, 2014) and/or prey availability (Wise 1979; Miyashita 1992). In this study, we focused on the vegetation structure of rice and abundant weeds, as well as the biomass of abundant arthropod groups, such as chironomidae and other nematocera, brachycera, and hoppers including Cicadellidae and Delphacidae, and the pecky rice bug Stenotus rubrovittatus, as potential limiting factors of the spiders.

\section{Methods}

\section{Study site}

A field survey was conducted in the area surrounding Kabukuri-numa at Osaki City, Miyagi Prefecture, Northern Japan $\left(38^{\circ} 37^{\prime} \mathrm{N}, 141^{\circ} 07^{\prime} \mathrm{E}\right)$, where many WF paddies (total area: about $0.2 \mathrm{~km}^{2}$ ) have been cultivated (Kurechi 2007) since around 1998. The mean annual precipitation from 2002 to 2007 was approximately $1166 \mathrm{~mm}$, and the mean temperature in August during the same period was $23.6^{\circ} \mathrm{C}$ (Japan Meteorological Agency 2012). In this region, insecticides for Stenotus rubrovittatus (Hemiptera: Miridae), the most abundant and influential rice pest (Yoshioka et al. 2011; Takada et al. 2012; Yoshioka et al. in press), are applied to most of the conventional paddy fields after heading of rice plants in early August, when spider diversity in paddies is at the highest level (Oyama et al. 2005). Field measurements were conducted twice, just before and after application of the insecticides to conventional fields, with the expectation that spider diversity decreases in conventional paddies, while remaining unchanged in WF ones after the application of insecticide to conventional fields.

In this area, clusters of WF paddies were distributed among conventionally managed paddies. The WF fields have been maintained by using similar management practices that include the application of natural fertilizers, such as fertilizer made from fish parts, and exclude chemical fertilizers, herbicides, and insecticides.
Before seedling transplanting in the middle of May, the natural fertilizers are applied to WF fields. Some of the fields that did not receive herbicide application were dominated by weeds, such as Monochoria vaginalis var. plantaginea. So farmers do the mechanical weeding once or twice in June. WF fields are flooded all year. Even in winter (not rice-growing season) WF fields are flooded for providing suitable habitats for waterfowl (Kurechi 2007). A typical farming schedule in the conventional paddies is as follows. Fungicides (Tetrachloroisophthalonitrile or hydroxyisoxazole and Metalaxyl) are applied to young rice plants in seedling boxes, and herbicides (indanofan, bensulfuronmethyl, and clomeprop $\left(5 \mathrm{~kg} \mathrm{ha}^{-1}\right)$ or Pyriminobac-methyl, bromobutide, bensulfuronmethyl, and pentoxazone $\left.\left(10 \mathrm{~kg} \mathrm{ha}^{-1}\right)\right)$ are applied directly to the field after seedling transplanting in early May. Insecticides (etophenprox (2-3 $\left.1 \mathrm{ha}^{-1}\right)$ ) for rice leaf beetle Oulema oryzae Kuwayama are applied to the fields and then water is drained from the field for about ten days to stabilize rice yield and increase soil hardness in early June. After heading of rice plants in early August, insecticides for pecky rice bugs (dinotefuran $\left(30 \mathrm{~kg} \mathrm{ha}^{-1}\right)$ ) are applied once or twice to the field. The insecticides are applied to many of the conventional rice fields by radio-controlled helicopters. Most conventional paddies are seasonally dried-up after harvesting.

\section{Field survey}

A total of $31 \mathrm{WF}$ and 7 conventional paddies were selected in an area of approximately $20 \mathrm{~km}^{2}$. The mean (SD) area of the study fields was $2100.8 \pm 438.2 \mathrm{~m}^{2}$ and $1780.3 \pm 523.7 \mathrm{~m}^{2}$ for the WF and conventional fields, respectively. Rice seedlings were transplanted in May 2007 at a mean (SD) density of $21.20 \pm 2.0$ hills $/ \mathrm{m}^{2}$ and $23.24 \pm 2.0$ hills $/ \mathrm{m}^{2}$ in the WF and conventional fields, respectively. In August 2007, net samplings (20 sweeps with a 36-cm-diameter insect net) for spiders and their potential prey were performed at the center of each field just before and after using insecticides for pecky rice bugs in conventional fields (insecticide application: 6, 18-19 August, first survey: 1-4 August; Second survey: 15-19 August). The sweeping sampling is an excellent method to collect invertebrates inhabiting the uppermost vegetation layer in paddies easily. Invertebrate body mass was calculated as mass $(\mathrm{mg})=0.0305 \times$ (body length $(\mathrm{mm}))^{2.62}$ (Rogers et al. 1976) to measure the abundance of potential prey for spiders. As indices of habitat complexity, we measured rice height of six randomly chosen hills and counted the number of individuals of the most abundant weed (M. vaginalis) within a $1 \times 3 \mathrm{~m}^{2}$ quadrant at the center of each field (e.g., Rypstra et al. 1999, Miyashita and Takada 2007). 
Table 1 Independent variables used in the generalized linear mixed effect models for identifying limiting factors of spider density and species richness in winter-flooded (WF) paddies

\begin{tabular}{lccc}
\hline Independent variables & Mean & Range & Tolerance values \\
\hline Habitat complexity & & & \\
Mean rice height $(\mathrm{cm})$ & 67.34 & $59.67-77.83$ & 0.903 \\
$\begin{array}{l}\text { Monochoria vaginalis } \\
\text { (no.individuals/3 m²) }\end{array}$ & 67.42 & $0-393$ & 0.794 \\
$\begin{array}{l}\text { Prey availability } \\
\text { (mg/20 sweeps with }\end{array}$ & & & \\
an insect net) & & & \\
Chironomid & 130.68 & $14.23-975.86$ & 0.837 \\
Other nematocera & 32.07 & $6.58-100.54$ & 0.913 \\
S. rubrovittatus & 7.08 & $0-65.37$ & 0.746 \\
Brachycera & 5.23 & $0.38-29.90$ & 0.831 \\
Hopper & 3.98 & $0.79-10.17$ & 0.823 \\
\hline
\end{tabular}

\section{Statistical analysis}

To evaluate the effects of the farming practices (WF vs. conventional) and the insecticides applied to conventional fields (before vs. after) on the numbers of individual spiders and spider species in paddies of both types, we applied generalized linear mixed effect models with Poisson error distribution because the dependent variables are count data. Fixed factors in the models were the main effects of the farming practice and the insecticide applications and their interaction, and the random factor was the effect of the

Table 2 Mean density of each spider species or family per field for WF and conventional paddies

\begin{tabular}{lccccc}
\hline Species/family & \multicolumn{2}{c}{$\begin{array}{c}\text { Before insecticide } \\
\text { application }\end{array}$} & & \multicolumn{2}{c}{$\begin{array}{c}\text { After insecticide } \\
\text { application }\end{array}$} \\
\cline { 2 - 3 } \cline { 5 - 6 } & WF & Conventional & & WF & Conventional \\
\hline Tetragnatha caudicula & 2.774 & 0.143 & & 0.406 & 0 \\
T. praedonia & 0.774 & 0.143 & & 0.469 & 0 \\
T. extensa & 0.194 & 0.143 & & 0.0406 & 0 \\
T. maxillosa & 0.484 & 0 & & 0.094 & 0 \\
T. squamata & 0.097 & 0 & & 0.031 & 0 \\
Pachygnatha & 0.516 & 0 & 0.406 & 0 \\
quadrimaculata & & & & 0 \\
P. clercki & 0.161 & 0 & & 0.344 & 0 \\
Lycosidae & 0.065 & 0 & 0.250 & 0 \\
Neoscona adianta & 0.065 & 0 & & 0 & 0 \\
Argiope bruennichii & 0.032 & 0.286 & & 0 & 0 \\
Larinioides cornutus & 0 & 0 & 0.063 & 0 \\
Linyphiidae & 0.032 & 0 & 0.281 & 0 \\
Thomiside & 0.032 & 0.143 & 0.031 & 0 \\
Theridiidae & 0 & 0 & 0.031 & 0 \\
Unknown spiders & & 0 & & 1.781 & 0.143 \\
\hline
\end{tabular}

paddy. The significance of each fixed effect was checked by using analysis of deviance and by checking for the reduction in residual deviance by reducing each effect by means of the Chi-squared test.

The factors limiting the density and diversity of spiders in the WF paddies were analyzed by using generalized linear mixed effect models with Poisson error distribution because the dependent variables are count data. We examined the limiting factors of spider density and species richness using only the data of the first survey to avoid redundant analyses, because spider density in the WF paddies tended to be higher in the first field survey than in the second (see Results) and the results obtained from preliminary analyses using the data of the second survey were similar to those of the first survey. This model included the number of individual spiders or spider species richness as the dependent variable, and

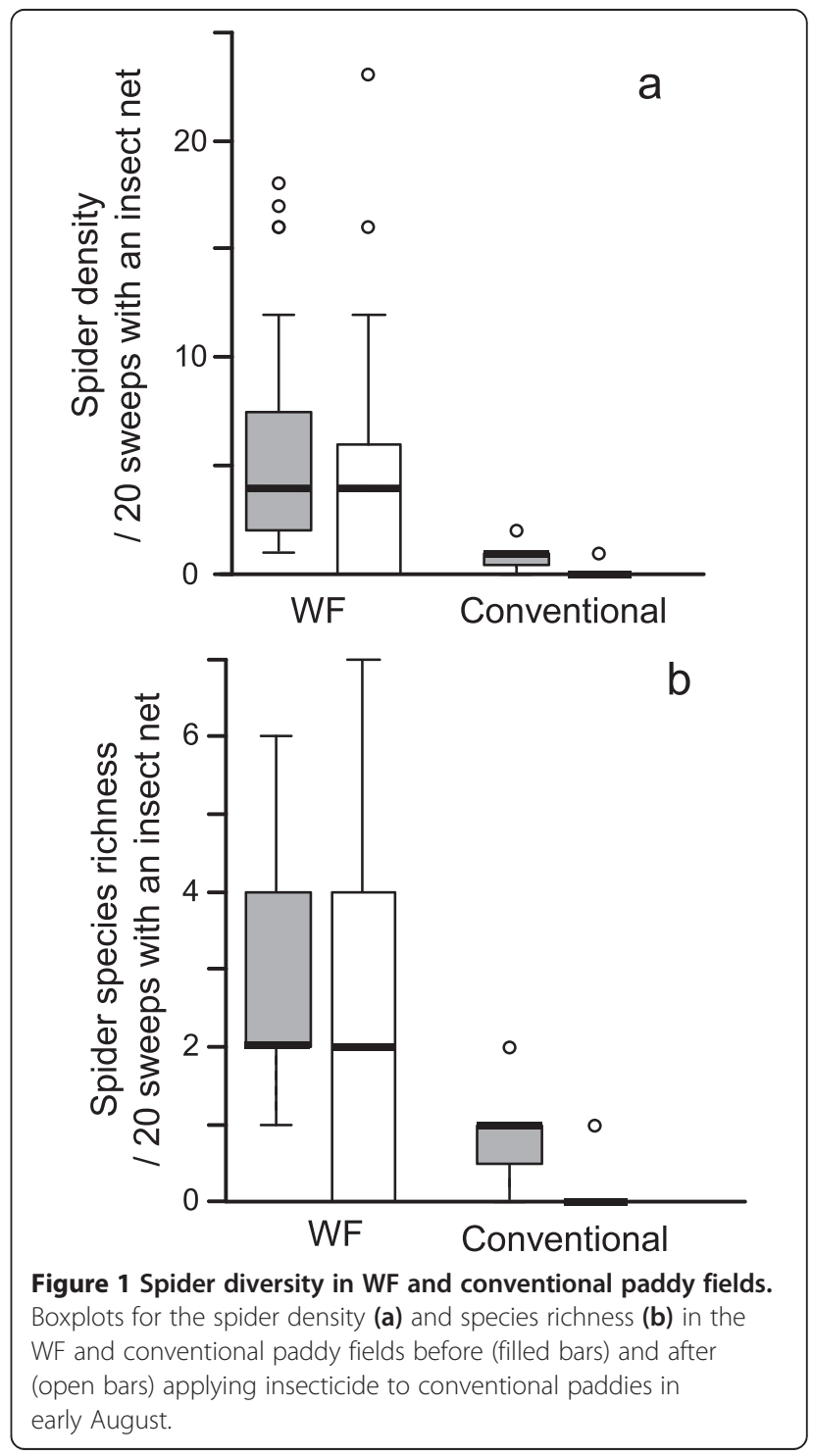


two indices of habitat complexity (mean rice height and $M$. vaginalis density) and the biomass of five prey groups as fixed factors (Table 1), with the paddy field as a random effect. All tolerance values between the fixed factors were greater than the critical value of 0.1 (Table 1), indicating no significant collinearity between them (Quinn and Keough 2002). Model selection for the generalized linear mixed effect models was performed using Akaike's Information Criterion (AIC). AIC was calculated for each possible combination of fixed factors, and the models with small AIC were chosen as optimal models. All statistical analysis was carried out using $R$ for Windows 2.13.1 ( $R$ Development Core Team 2011).

\section{Results}

A total of 234 spiders in 15 species or families were observed. Dominant spider species were Tetragnatha caudicula, T. praedonia, and T. extensa for web-building spiders and Pachygnatha quadrimaculata, P. clercki, and Lycosidae spp. for cursorial spiders (Table 2). Juveniles were identified only to family.

The main effect of farming practice (WF vs. conventional $)$ on spider density $\left(\chi_{1}^{2}=23.369, P<0.001\right)$ and species richness $\left(X_{1}^{2}=17.817, P<0.001\right)$ was highly significant, while the interaction effect of farming practice and insecticide application was significant on neither spider density nor species richness (density: $X_{1}^{2}=2.792$, $P=0.095$; species richness: $\left.\chi_{1}^{2}=3.204, P=0.073\right)$. This result indicates that spider density and species richness were higher in WF paddies than in conventional ones both before and after insecticide applications to conventional paddies (Figure 1). Since the main effect of insecticide application (before vs. after) was significant only for spider density (density: $X_{1}^{2}=5.920, P=0.015$; species richness: $\left.X_{1}^{2}=1.417, P=0.234\right)$, insecticide application to conventional paddies was suggested to reduce spider density in both the WF and conventional paddies (Figure 1). Moreover, the variations in spider density and species richness in the WF paddies seemed to increase after applying insecticide: the interquartile range--the difference between upper (75\% quartile) and lower (25\% quartile) hinges--of spider density was 5.5 before insecticide application, but 6 after (Figure 1a), and the interquartile range of spider species richness was 2 before insecticide application, but 4 after insecticide application (Figure 1b).

The best model for explaining the spider density and species richness in WF paddies included the biomass of chironomids and other nematocera (Table 3) but did not include any factors of habitat complexity, such as mean rice height or $M$. vaginalis density. These two groups of prey increased both spider density and species richness (Figure 2).

\section{Discussion}

We revealed that spider density and species richness were higher in the WF paddies than in the conventional ones both before and after insecticide application to conventional paddies for pecky rice bugs in early August. Moreover, our results suggest that the insecticide application decreased spider density in not only conventional paddies but also WF ones. The spider diversity in the WF paddies was significantly affected by the availability of two prey groups, chironomids and other nematocera.

Table 3 Estimated coefficients(SE) and information theoretic statistics of the top five and null (intercept only) models explaining spider density and species richness in WF paddies

\begin{tabular}{|c|c|c|c|c|c|c|c|c|c|c|c|}
\hline Rank & Intercept & $\begin{array}{c}\text { Rice } \\
\text { height }\end{array}$ & M. vaginalis & Chironomid & $\begin{array}{c}\text { Other } \\
\text { nematocera }\end{array}$ & S. rubrovittatus & Brachycera & Hopper & AIC & $\Delta \mathrm{AIC}$ & $w_{i}$ \\
\hline \multicolumn{12}{|c|}{ Spider density } \\
\hline 1 & $-0.941(0.457)$ & - & - & $0.473(0.092)$ & $0.014(0.004)$ & - & - & - & 52.10 & 0 & 0.119 \\
\hline 2 & $-0.717(0.471)$ & - & - & $0.460(0.090)$ & $0.013(0.004)$ & - & $-0.028(0.022)$ & - & 52.45 & 0.34 & 0.100 \\
\hline 3 & $0.844(1.736)$ & $-0.027(0.26)$ & - & $0.487(0.93)$ & $0.013(0.004)$ & - & - & - & 52.97 & 0.87 & 0.077 \\
\hline 4 & $-0.755(0.543)$ & - & $-0.031(0.53)$ & $0.445(0.0102)$ & $0.014(0.004)$ & - & - & - & 53.75 & 1.65 & 0.052 \\
\hline 5 & & & - & $0.473(0.091)$ & $0.013(0.004)$ & - & $-0.025(0.023)$ & - & 53.80 & 1.70 & 0.051 \\
\hline Null & $1.490(0.164)$ & & - & - & - & - & - & - & 73.44 & 21.33 & 0 \\
\hline \multicolumn{12}{|c|}{ Spider species richness } \\
\hline 1 & $-0.535(0.481)$ & - & - & $0.278(0.098)$ & $0.008(0.005)$ & - & - & - & 21.13 & 0 & 0.074 \\
\hline 2 & $-0.286(0.517)$ & - & - & $0.262(0.097)$ & $0.009(0.005)$ & - & - & $-0.053(0.044)$ & 21.63 & 0.50 & 0.057 \\
\hline 3 & $-0325(0.451)$ & - & - & $0.294(0.096)$ & - & - & - & - & 21.87 & 0.74 & 0.051 \\
\hline 4 & $-0372(0.515)$ & - & - & $0.268(0.099)$ & $0.007(0.005)$ & - & $-0.020(0.25)$ & - & 22.40 & 1.27 & 0.039 \\
\hline 5 & $-0.138(0.481)$ & - & - & $0.278(0.097)$ & - & - & $-0.025(0.025)$ & - & 22.73 & 1.60 & 0.033 \\
\hline Null & $0.960(0.111)$ & - & - & - & - & - & - & - & 28.68 & 7.55 & 0.002 \\
\hline
\end{tabular}

Ranking of the sub models is based on Akaike's information criterion. 

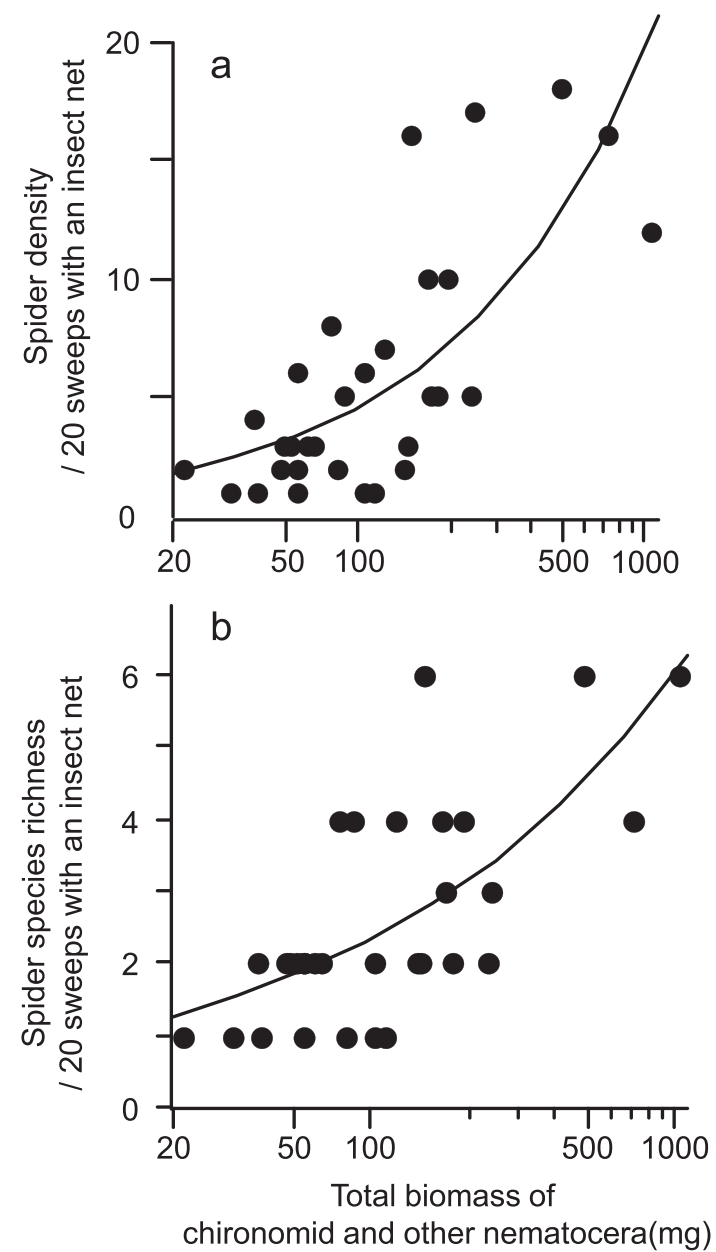

Figure 2 Spider diversity and their potential prey in WF paddy

fields. Relationships between total biomass of important prey (chironomids and other nematocera) and spider density (a) and species richness (b) in WF paddies before applying insecticide to conventional fields. Poisson regression lines are also shown.

The significant main effect of farming practice (WF vs. conventional) on spider density and species richness appears to indicate that these values were already lower in conventional fields than in WF ones before the insecticide application to conventional paddies (Table 2, Figure 1). At least four possible explanations for the farming practice effect can be identified. First, fungicides applied to young rice plants in seedling boxes, herbicides and insecticides early in the rice-growing season may be responsible for the reduced spider diversity in conventional fields during the early-growing season. Such agricultural chemicals are known to affect invertebrates (Oyama and Kidokoro 2003; Wilson et al. 2008; Amano et al. 2011) and were probably responsible for decreasing the number of spider prey in the paddies. The second mechanism for the farming practice effect on the spiders is due to the drainage of conventional paddies in early June. Drainage dries and hardens the soil in conventional paddies (see Study site) and likely decreases the number of aquatic invertebrate, including juveniles of dipterous insects, which are important prey for spiders (Ishijima et al. 2006; Tahir and Butt 2009). Third, organic fertilizer applied to the WF fields before seedling transplanting might increase spider diversity due to increasing the availability of important prey for spiders. Previous studies have reported that detrital subsidy, such as organic fertilizer, enhances spider populations indirectly through increasing detritivores, such as chironomids and collembolas (Murata 1995; Settle et al. 1996; Halaj and Wise 2002). Finally, tubificid worms as well as waterfowl fertilize WF paddy soil with their feces (Kurechi 2007), which may increase spider diversity due to increasing the availability of important prey for spiders. Because WF fields are flooded all year, tubificid worms are known to active even in winter, fertilizing the soil in WF fields. On the other hand, conventional fields are dried-up after harvesting. Clarification of these causalities requires manipulative experiments controlling each component with many replications.

The main effect of insecticide application (before vs. after) on spider density was also significant, suggesting the insecticides applied to conventional fields may decrease spider density in not only conventional but also WF paddies, despite not applying insecticides to WF paddies directly. One possible explanation is as follows. WF and conventional paddy fields are spatially intermingled in the study area, so insecticides for pecky rice bugs sprayed onto the conventional rice fields by radiocontrolled helicopters may easily diffuse into adjacent WF paddies and consequently affect spider density. Increased variation in the spider density and species richness in WF paddies after insecticide application (Figure 1) appears to support this possibility, because the intensity of the negative effect of the insecticides on spiders inhabiting the WF paddies may vary depending on the distance between the WF and conventional paddies. If so, increasing the spatial gathering of WF paddies will lead to an increase in the number of spiders in each WF paddy due to avoiding the diffusion of insecticides sprayed by radio-controlled helicopters. Enhancement of spider populations by strategic spatial placement of WF paddies may also suppress damage by pecky rice bugs in WF paddies. Spider species with high abundance in the WF paddies were also shown to predate pecky rice bugs through previous DNA-based gut-content analysis (Kobayashi et al. 2011; Takada et al. 2013). Moreover, Tetragnatha spp. spiders were revealed to suppress bug density and the consequent damage in organic paddies fields (Takada et al. 2012).

Spider diversity in WF paddies increased with the increasing abundance of chironomids and other 
nematocera. This was revealed by statistical analysis of the limiting factors of spider diversity (Table 3). Because we used a comparative approach, the casual relationship between spiders and these insects was no proven in this study. However, previous studies have suggested that these dipterous insects are frequently consumed by the spiders in paddies (Ishijima et al. 2006; Tahir and Butt 2009). Taken together, the dipterous insects most likely limit spider diversity in WF paddy fields. Our study is one of the few that provides evidence of the correlation between the abundance of important prey and increased spider diversity in paddies, with many replications.

Spiders and their potential prey were collected only by one method (i.e. sweeping sampling) in this study. Sweeping sampling is an excellent method to collect invertebrates inhabiting the uppermost vegetation layer in paddies easily. But it is necessary to use other methods (e.g., direct counting), to estimate spiders inhabiting the bottom layer, such as Lycosidae.

Many studies have shown that flooding rice paddies can provide suitable habitats for waterfowl (Elphick and Oring 1998; Tourenq et al. 2003; Kurechi 2007). The present study suggests that in WF paddies the diversity of generalist predators is higher than in conventional paddies during the rice-growing season. Moreover, a combination of management at both the landscape and field level seems to be more effective for increasing spider diversity in WF paddies. Spiders are not only important natural enemies of various insect pests (Kiritani et al. 1970; Oraze et al. 1989; Takada et al. 2012), but also important prey for larger predators, such as frogs (e.g., Hirai and Matsui 2001) and larger spiders (e.g., Ishijima et al. 2006) in paddies. Taken together, the enhancement of spider diversity in WF paddy fields might achieve both biological control and biodiversity conservation in rice paddy ecosystems.

\section{Competing interests}

The authors declare that they have no competing interests.

\section{Authors' contributions}

MBT conducted field surveys and wrote the paper. ST, SI, and TM collected field data. IW designed field surveys and wrote the paper. All authors discussed the results and commented on the paper. All authors read and approved the final manuscript.

\section{Acknowledgements}

This study was made possible by the help of the farmers of the paddy fields in Osaki City and by farmers at the Osaki City Hall. We would also like to thank J. Oyama, A. Yoshioka, and Y. G. Baba for providing helpful comments and A. Tanikawa and Y. G. Baba for identification of the spiders. This study was supported by a Grant-in-Aid for Young Scientists (B) (23780049) and the 21 st Century COE Program at the University of Tokyo "Biodiversity and Ecosystem Restoration Research Project".

\section{Author details}

Institute for Sustainable Agro-ecosystem Services, University of Tokyo, Midori-cho, Nishi-Tokyo, Tokyo 188-0002, Japan. ${ }^{2}$ Department of Environmental Science, Faculty of Science, Toho University, Miyama 2-2-1, Funabashi 274-8510, Japan. ${ }^{3}$ Rice Paddies Japan, Tajiri, Osaki-city, Miyagi 989-4302, Japan. ${ }^{4}$ National Institute for Rural Engineering, Kannondai, Tsukuba-shi, Ibaraki 305-8609, Japan. ${ }^{5}$ School of Agricultural and Life Sciences, University of Tokyo, Yayoi, Bunkyo-ku, Tokyo 113-8657, Japan.

Received: 25 February 2014 Accepted: 31 July 2014

Published: 9 August 2014

\section{References}

Amano T, Kusumoto Y, Okamura H, Baba YG, Hamasaki K, Tanaka K, Yamamoto S (2011) A macro-scale perspective on within-farm management: how climate and topography alter the effect of farming practices. Ecol Lett 14:1263-1272. doi:10.1111/j.1461-0248.2011.01699.x

Bengtsson J, Ahnström J, Weibull A-C (2005) The effects of organic agriculture on biodiversity and abundance: a meta-analysis. J Appl Ecol 42:261-269, doi:10.1111/j.1365-2664.2005.01005.x

De Ponti T, Rijk B, Van Ittersum MK (2012) The crop yield gap between organic and conventional agriculture. Agricult Sys 108:1-9

Elphick CS, Oring LW (1998) Winter management of Californian rice fields for waterbirds. J Appl Ecol 35:95-108. doi:10.1046/j.1365-2664.1998.00274.x

Fasola M, Ruiz X (1997) Rice farming and waterbirds: integrated management in an artificial landscape. In: Pain DJ, Pienkowski MW (eds) Farming and birds in Europe: the common agricultural policy and its implications for bird conservation. Academic, London, United Kingdom, pp 210-235

Halaj J, Wise DH (2002) Impact of a detrital subsidy on trophic cascades in a terrestrial grazing food web. Ecology 83:3141-3151, doi:10.1890/0012-9658 (2002)083[3141:IOADSO]2.0.CO;2

Hirai T, Matsui M (2001) Food habits of an endangered Japanese frog, Rana porosa brevipoda. Ecol Res 16:737-743, doi:10.1046/j.1440-1703.2001.00430.x

Ishijima C, Taguchi A, Takagi M, Motobayashi T, Nakai M, Kunimi Y (2006) Observational evidence that the diet of wolf spiders (Araneae: Lycosidae) in paddies temporarily depends on dipterous insects. Appl Entomol Zool 41:195-200. doi:10.1303/aez.2006.195

Japan Meteorological Agency (2012) Japan Meteorological Agency, http://www. jma.go.jp/jma/indexe.html Accessed 5 February 2014

Kiritani K, Hokyo N, Sasaba T, Nakasuji F (1970) Studies on population dynamics of the green rice leafhopper, Nephotettix cincticeps UHLER: Regulatory mechanism of the population density. Res Popul Ecol 12:137-153. doi:10.1007/BF02511560

Kobayashi T, Takada M, Takagi S, Yoshioka A, Washitani I (2011) Spider predation on a mirid pest in Japanese rice fields. Basic Appl Ecol 12:532-539. doi:10.1016/j.baae.2011.07.007

Kurechi M (2007) Restoring rice paddy wetland environments and the local sustainable society - project for achieving coexistence of rice paddy agriculture with waterbirds at Kabukuri-numa, Miyagi prefecture, Japan -. Glob Environ Res 12:141-152

Langellotto GA, Denno RF (2004) Responses of invertebrate natural enemies to complex-structured habitats: a meta-analytical synthesis. Oecologia 139:1-10. doi:10.1007/s00442-004-1497-3

Miyashita T (1992) Food limitation of population density in the orb-web spider, Nephila clavata. Res Popul Ecol 34:143-153. doi:10.1007/BF02513527

Miyashita T, Takada M (2007) Habitat provisioning for aboveground predators decreases detritivores. Ecology 88:2803-2809, http://dx.doi.org/10.1890/061633.1

Murata K (1995) The interaction between spiders and prey insects under the sustainable cultivation. -Influence of the paddy field spiders and the prey insects. Acta Arachnol 44:83-96

Oraze MJ, Grigarick AA (1989) Biological control of aster leafhopper (Homoptera: Cicadellidae) and midges (Diptera: Chironomidae) by Pardosa ramulosa (Araneae: Lycosidae) in California rice fields. J Econ Entomol 82:745-749

Oyama J, Kidokoro T (2003) Effects of insecticide application in rice cultivation on densities of spiders, larvae of Sympetrum and Chironomidae species in a paddy field. Ann Rept Plant Prot North Japan 54:123-125 (in Japanese with English summary)

Oyama J, Kidokoro T, Ono T (2005) Effect of pesticide on natural enemy in paddy field. Bull Miyagi Prefect Furukawa Agric Exp Stn 5:31-42 (in Japanese with English summary) 
Quinn GP, Keough MJ (2002) Experimental design and data analysis for biologists. Cambridge University Press, Cambridge

R Development core team (2011) R: A Language and Environment for statistical computing. R foundation for statistical computing, Vienna

Rogers LE, Hinds WT, Buschbom RL (1976) A general weight vs. length relationship for insects. Ann Entomol Soc Am 69:387-389

Rypstra AL, Carter PE, Balfour RA, Marshall SD (1999) Architectural features of agricultural habitats and their impact on the spider inhabitants. J Arachnol 27:371-377

Settle WH, Ariawan H, Astuti ET, Cahyana W, Hakim AL, Hindayana D, Lestari AS, Sartanto P (1996) Managing tropical rice pests through conservation of generalist natural enemies and alternative prey. Ecology 77:1975-1988

Tahir HM, Butt A (2009) Predatory potential of three hunting spiders inhabiting the rice ecosystems. J Pest Sci 82:217-225. doi:10.1007/s10340-008-0242-9

Takada M, Miyashita T (2004) Additive and non-additive effects from a larger spatial scale determine small-scale densities in a web spider Neriene brongersmai. Popul Ecol 46:129-135. doi:10.1007/s10144-004-0187-7

Takada MB, Miyashita T (2014) Dispersal-mediated effect of microhabitat availability and density dependence determine population dynamics of a forest floor web spider. J Anim Ecol, doi:10.1111/1365-2656.12213

Takada MB, Yoshioka A, Takagi S, Iwabuchi S, Washitani I (2012) Multiple spatial scale factors affecting mirid bug abundance and damage level in organic rice paddies. Biol Control 60:169-174. doi:10.1016/j.biocontrol.2011.11.011

Takada MB, Kobayashi T, Yoshioka A, Takagi S, Washitani I (2013) Facilitation of ground-dwelling wolf spider predation on mirid bugs by horizontal webs built by Tetragnatha spiders in organic paddy fields. J Arachnol 41:31-35. doi:10.1636/P12-30.1

Tourenq C, Sadoul N, Beck N, Mesléard F, Martin J-L (2003) Effects of cropping practices on the use of rice fields by waterbirds in the Camargue, France. Agric Ecosyst Environ 95:543-549. doi:10.1016/S0167-8809(02)00203-7

Washitani I (2007) Restoration of biologically-diverse floodplain wetlands including paddy fields. Glob Environ Res 11:135-140

Wilson AL, Watts RJ, Stevens MM (2008) Effects of different management regimes on aquatic macroinvertebrate diversity in Australian rice fields. Ecol Res 23:565-572. doi:10.1007/s11284-007-0410-z

Wise DH (1979) Effects of an experimental increase in prey abundance upon the reproductive rates of two orb-weaving spider species (Araneae: Araneidae). Oecologia 41:289-300. doi:10.1007/BF00377433

Yoshioka A, Takada M, Washitani I (2011) Facilitation of a native pest of rice, Stenotus rubrovittatus (Hemiptera: Miridae), by the non-native Lolium multiflorum (Cyperales: Poaceae) in an agricultural landscape. Environ Entomol 40:1027-1035, doi:10.1603/EN11032

Yoshioka A, Takada MB, Washitani I Landscape effects of a non-native grass facilitate source populations of a native generalist plant bug, Stenotus rubrovittatus in a heterogeneous agricultural landscape. J Insect Sci, In Press

Zehnder G, Gurr GM, Kühne S, Wade MR, Wratten SD, Wyss E (2007) Arthropod pest management in organic crops. Annu Rev Entomol 52:57-80. doi:10.1146/annurev.ento.52.110405.091337

doi:10.1186/2193-1801-3-418

Cite this article as: Takada et al: Comparison of generalist predators in winter-flooded and conventionally managed rice paddies and identification of their limiting factors. SpringerPlus 2014 3:418.

\section{Submit your manuscript to a SpringerOpen ${ }^{\odot}$ journal and benefit from:}

- Convenient online submission

- Rigorous peer review

- Immediate publication on acceptance

- Open access: articles freely available online

- High visibility within the field

- Retaining the copyright to your article

Submit your next manuscript at $\gg$ springeropen.com 